\title{
The Barriers and Facilitators of Self-Management Among Adults with Type 2 Diabetes Mellitus: A Trans Theoretical Model (TTM)-Based Mixed Method Study in Iran
}

This article was published in the following Dove Press journal:

Diabetes, Metabolic Syndrome and Obesity: Targets and Therapy

\author{
Maryam Zare $\mathbb{D D}^{\prime}$ \\ Ali Tarighat-Esfanjani ${ }^{2}$ \\ Maryam Rafraf ${ }^{2}$ \\ Abdolreza Shaghaghi ${ }^{3}$ \\ Mohammad Asghari-Jafarabadi ${ }^{4}$ \\ Mahmood Shamshiri (iD ${ }^{5}$ \\ 'Department of Nutrition, Khalkhal \\ University of Medical Sciences, Khalkhal, \\ Iran; ${ }^{2}$ Nutrition Research Center, Faculty \\ of Nutrition and Food Sciences, Tabriz \\ University of Medical Sciences, Tabriz, \\ Iran; ${ }^{3}$ Department of Health Education \\ and Promotion, Faculty of Health, Tabriz \\ University of Medical Sciences, Tabriz, \\ Iran; ${ }^{4}$ Road Traffic Injury Research \\ Center, Tabriz University of Medical \\ Sciences, Tabriz, Iran; ${ }^{5}$ School of Nursing \\ and Midwifery, Ardabil University of \\ Medical Sciences, Ardabil, Iran
}

\begin{abstract}
Aim: This study planned to determine:(1) the behavioral intention or profile of patients with type 2 diabetes mellitus (T2DM) based on the stages of the change model, and(2) to explore the perceived facilitators and barriers of self-management (SM) in a sample of Iranian patients with T2DM.

Methods: This was a mixed method study, accomplished in two phases. In the quantitative phase, 246 subjects with T2DM participated. They were classified according to items such as regular use of blood-glucose-lowering drugs, having a healthy diet and performing physical activity to pre-action and action groups. Socio-demographic and anthropometric information were collected, and a phenomenological qualitative study was conducted, and data collection continued until saturation achieved by 10 subjects in pre-action and 12 subjects in action groups. Four focus group discussions in the field of SM were accomplished. Analysis of quantitative and qualitative data was conducted by the SPSS and MAXQDA software, respectively.

Results: The mean age and duration of illness among the subjects were $53.9 \pm 7.1$ and 6.9 \pm 4.9 years, respectively. The barriers of SM in action and pre-action stages were as follows: lower socio-economic status, poor performance of treatment team, physical-intellectual factors and lack of planning to change. The facilitators stated in the pre-action and action stage in the field of SM were satisfaction from treatment, planning, belief in diabetes, treatment team's support, nutritional knowledge, and religious beliefs.

Conclusion: This study indicated facilitator and barrier factors in SM based on TTM in action and pre-action groups. Healthcare professionals should consider these findings to improve the patients' outcomes.
\end{abstract}

Keywords: diabetes mellitus type 2, self-management, healthy diet, exercise

\section{Introduction}

Diabetes is a chronic metabolic disorder characterized by elevated blood glucose level, which could lead to serious complications if it is not diagnosed or managed properly. Type 2 diabetes mellitus (T2DM) occurs when the body cannot effectively use the insulin produced by pancreas; hence, blood glucose level rises. ${ }^{1}$ In 2014 , an estimated 422 million adults were living with diabetes worldwide which is about four times higher than the conjectured figure, i.e. 108 million in 1980. During this period the prevalence of $\mathrm{T} 2 \mathrm{DM}$ has increased from $4.7 \%$ to $8.5 \%$ in adults' population. ${ }^{2}$ Delayed diagnosis and deficient control measures could lead to a number of devastating consequences including macro-vascular (heart failure and
Correspondence: Ali Tarighat-Esfanjani Nutrition Research Center, Faculty of Nutrition and Food Sciences, Tabriz University of Medical Sciences, Tabriz, 5I666I47II, Iran

Tel $+98-4 \mid-33362117$

Fax +98-4I-33340634

Email Tarighat45@gmail.com 
stroke) and micro-vascular (nephropathy, neuropathy leading to amputation and retinopathy leading to blindness) complications in patients afflicted with diabetes. ${ }^{3}$

It has been indicated that self-management (SM) of chronic diseases reduces the burden of diseases on patients and improve treatment outcome. In line with such recommendations, SM education for patients with T2DM has been proven to be beneficial for better therapeutic outcomes and delaying prolonged complications. ${ }^{4}$ The conventional SM of T2DM included medication adherence, lifestyle modification and regular checkups by a professional health care provider. However, existent research evidence indicates that successful SM of the disease faces challenges and difficulties. ${ }^{5,6}$ Implementing health policies with desired level of efforts for prevention strategies can overcome the impediments that hinder selfcontrol of the disease and prevent its devastating complications. In the absence of effective and sustainable strategies to reinforce active engagement of patients with T2DM in their disease management process, the proceeding results could be overwhelming for patients, their families and communities. Patient's competency and psycho-emotional readiness to change and interplay several contextual factors influence their preparedness in making informed decisions. ${ }^{7-12}$ Due to the significance of SM on T2DM alleviation and the patients' quality of life, recognition of potential facilitators or obstacles of virtuous SM could be a determining field in investigating pertinent health care provision. ${ }^{13}$

In most health care centers, certain models are used for assessing and evaluating SM among T2DM patients. ${ }^{6}$ One of these models is TTM, which is widely used in healthpromoting systems for guiding behavioral changes. The TTM enhances individual's motivation for SM. This model comprised four constructs: stages of change (SOC), processes of change, decisional balance and selfefficacy. Decisional balance means pros and cons, and in this construct, an individual assess benefits and barriers of changing his/her behavior and focuses on the importance of positive and negative perceptions regarding the outcome of changing his/her behaviors.

To have a realistic view on the SM intermediates of TTM, the SOC was used to segment study participants based on their progress across the spectrum of the model's phases, i.e. pre-contemplation, contemplation, preparation, action and maintenance. In the pre-contemplation stage, adults with T2DM have no intention to take a proposed action within the next 6 months while in the contemplation phase patients with T2DM taking action within the next 6 months is intended. Those in the preparation phase are pondered to do the considered behavior within the next 30 days and in the action phase, the patients with T2DM actually change his/her behavior. The last span of the change process is consistently continuation in prolong of the aspired behavior for over 6 months. ${ }^{14,15}$

Objectives: Thus, this study planned to determine: 1) the behavioral status of the patients with T2DM based on the SOC construct of TTM model, and 2) to explore perceived facilitators and barriers of SM in a sample of Iranian patients with T2DM.

\section{Materials and Methods Study Design}

A mixed method sequential explanatory design was applied in this study. The study was conducted in two phases; first, the quantitative data were collected followed by qualitative data. The purpose of the qualitative phase was to explain and interpret the findings of the quantitative phase. For example, a survey may be used to collect quantitative data from a larger group. Members of that group may then be selected for interviews where they can explain and offer insights into their survey answers.

To divide the study population into different interview groups based on their progress across phases of TTM and to inform the qualitative phase of the study, a preliminary quantitative probing study was conducted. Based on the findings of this initiatory phase, a phenomenological qualitative study was conducted through utilizing focus group discussions (FGD) in a typical sample of Iranian with T2DM regarding potential barriers or facilitators that could influence their SM practices.

\section{Subjects Selection}

The convenient sampling method was used to recruit patients with T2DM referring to a private clinic in the city of Ardabil, North West of Iran. Medical profiles of 510 patients with T2DM were assessed for inclusion criteria, i.e. being diagnosed with T2DM for more than a year, being 30-70 years old, using glucose-lowering drugs (BGLDs), not having renal, hepatic, cognitive, learning, visual and hearing disorders and having glycated hemoglobin $(\mathrm{HbA} 1 \mathrm{C})$ more than $7 \%$ or fasting blood glucose $(\mathrm{FBG})>126 \mathrm{mg} / \mathrm{dl} .{ }^{16,17}$ Exclusion criteria were using insulin, following specific diets, having pregnancyrelated diabetes and breast-feeding, and patients with severe complications. After checking the patients' laboratory test results, and being assured of their congruousness with the inclusion criteria, 246 participants meeting the preliminary inclusion criteria were invited to participate in the study. The 
study aims and procedures were thoroughly explained to the selected participants.

\section{Quantitative Phase}

Data about the participants' socio-demographic and anthropometric status and family history of T2DM were collected through asking a few simple questions. A researcher-designed questionnaire was also applied to collect data to classify the participants according to TTM phases. The questions were about regular use of BGLDs, following of a healthy diet and a sufficient level of physical activity (PA). Content and face validity of the questionnaire were assessed by a panel of experts. Construct validity was carried out by exploratory factor analysis. The validity and reliability of the questionnaire were satisfying.

In BGLDs and the PA section of the SM questionnaire, the first choice of the multiple-choice questions referred to pre-contemplation, the second to contemplation, and the third, fourth, and fifth ones to preparation, action, and maintenance, respectively. In the healthy diet section, the Likert scale was used, and for allocation of subjects in each stage, the mean scores were considered. Hereby, those who obtained scores between 8 and 14 were in the precontemplation section, while the scores of 15-20, 21-26, 27-32, and 33-40 indicated the contemplation, preparation, action, and maintenance sections, respectively.

According to the SOC construct of TTM, the patients were divided into pre-action (pre-contemplation, contemplation and preparation) and action (action, and maintenance) stages. According to the scale, a score of 1-3 indicated that the patients were in the pre-action stage, and a score of 4-5 indicated that the patients were in the action stage in BGLDs and PA. Regarding following a healthy diet, the mean score was obtained to determine each patient's position. A score of 8-26 indicated that the patients were in the pre-action stage. In addition, a score of 27-40 displayed that the patients were in the action stage. ${ }^{18}$ According to the SOC construct of TTM, the patients were divided into pre-action and action stages. Afterward, they were assessed based on the facilitators and inhibitors of SM related to the decisional balance construct of TTM.

\section{The Study Complimentary Qualitative Phase}

Focus group participants were selected from the quantitative phase subjects in two groups, pre-action and action SOC of TTM, based on the purposive sampling method:
Written informed consent to FGD was obtained from patients with T2DM willing to participate in FGD. Individual group meetings were also held to assess the facilitating and inhibiting factors of SM among the patients.

In each focus group, 12 patients with T2DM were invited, but 10 and 12 patients participated in the study, respectively. In both pre-action and action groups, two FGDs were considered. The meetings of the focus groups were held in a suitable and private room in a private clinic. The meetings were conducted in 60-90 minutes in the winter of 2017. In addition, a female researcher (nutritionist) supervised these meetings as a viewer to facilitate the group discussions.

The FGD began with a general and open-ended question like "How is life with diabetes?" Afterward, every patient described his/her disease in one way. The next and pursuing questions were based on the information that the patient revealed. If needed, probing questions were also asked to achieve the purpose of the study. Information gathering in FGD continued until data saturation, which data were repeated in categories. All FGDs were recorded by digital recording appliances.

The decisional balance construct of TTM was assessed by gathering data in the qualitative section of the study. The qualitative phase was conducted based on the focus group guidelines. ${ }^{19}$

\section{Statistical Analysis}

\section{The Study Preliminary Quantitative Phase}

Descriptive analyses: frequencies (percentage) and mean [standard deviation (SD)] were performed for quantitative phase data. Statistical analysis was conducted using the SPSS Version 21 software (SPSS Inc. IL, Chicago, USA).

\section{The Study Complimentary Qualitative Phase}

Qualitative analysis was conducted by the MAXQDA 12 software. All interviews were transcribed and coded as follows: the data line by line; several times and the main concept and important sentences were extracted, summarized, and the codes were registered. The codes were categorized based on their similarities in the sub-themes. In addition, each of these sub-themes established the major themes in accordance with their resemblance. The first categories and the axi-coding were prepared, the data were categorized, the sub-themes were determined and the major themes were specified. Additionally, to be assured of the categorized codes, the subthemes and major themes were corrected. One researcher implemented all these works, and after the primary coding for reliability, several researchers authorized them. ${ }^{20,21}$ 


\section{Results}

\section{Quantitative Phase}

In the quantitative phase of this study, 246 patients with T2DM participated, of whom $45.5 \%$ were male, and the rest were female. Table 1 presents the socio-demographic and anthropometric information.

\section{Qualitative Phase}

The study population in the qualitative phase was 22 patients diagnosed with T2DM (10 men and 12 women) with the mean age of $52.5 \pm 8.8$ years. In this study, 10 patients with the mean age of $51.5 \pm 6.9$ years (35-61 age range) participated in the pre-action group. The mean disease history was $6.3 \pm 4.8$ years. In the pre-action group, $33 \%$ and $67 \%$ were male and female, respectively. Furthermore, $8 \%$ were educated in the SM field, and $92 \%$ were less educated in relation to SM. Forty-two percent had a family history of diabetes, $33 \%$ of the patients were overweight, and $67 \%$ were obese. Regarding the BGLDs, $42 \%$ were in the pre-contemplation stage, $33 \%$ were in the contemplation stage, and $25 \%$ were in the preparation stage. For following a healthy diet, $8 \%$ were in the precontemplation stage, $42 \%$ were in the contemplation stage, and $50 \%$ were in the preparation stage. In addition, regarding PA, $68 \%, 16 \%$, and $16 \%$ were in pre-contemplation, contemplation and preparation stages, respectively.

In the action group (action and maintenance), 12 patients were studied. Their mean age was $54 \pm 9.9$ years with the age range of 37-70. The mean disease history was $7 \pm 7.9$ years. In the action group, $60 \%$ were male, and $40 \%$ were female. Moreover, $60 \%$ were educated about SM, $70 \%$ had a family history of diabetes. In addition, $70 \%$ of

Table I Socio-Demographic and Anthropometric of the Participants, $\mathrm{N}=246$

\begin{tabular}{|c|c|c|}
\hline Demographic Variables & Mean \pm SD & Number (\%) \\
\hline $\begin{array}{l}\text { Age (years) } \\
\text { Mean duration years of disease } \\
\text { Weight } \\
\text { Height } \\
\text { Family History T2DM }\end{array}$ & $\begin{array}{l}53.9 \pm 7.1 \\
6.9 \pm 4.9 \\
82.7 \pm 12.5 \\
162.2 \pm 9.4\end{array}$ & $155(63)$ \\
\hline $\begin{array}{l}\text { Education level } \\
\text { University education } \\
\geq \text { High school diploma } \\
\leq \text { Middle school diploma }\end{array}$ & & $\begin{array}{l}23(9.5) \\
52(20.8) \\
172(69.7)\end{array}$ \\
\hline
\end{tabular}

Notes: High school is ninth to twelfth grade. Middle school is between seventh and ninth grade.

Abbreviations: SD, Standard deviation; T2DM, Type 2 diabetes mellitus. the patients were overweight, and $30 \%$ were obese. To use BGLDs, $10 \%$ were in the action stage, $90 \%$ were in the maintenance stage. About following a healthy diet, 90\% were in the action stage, $10 \%$ were in the maintenance stage. In addition, in relation to having PA, $20 \%$ were in the action stage, $80 \%$ were in the maintenance stage.

In the action group, 12 patients participated in the field of inhibiting SM (an appropriate usage of BGLDs) and stated three major themes, and the subjects stated, "Chemical medicine's side effects causes no to use BGLDs". Following a healthy diet had 3 major themes, and the subjects stated, "Feeling dizzy when eating is delayed" and "Separating food from family because of heartburn is caused by medications".

The subjects stated three major themes in relation to having PA. One of the subjects said, "Cold weather makes me not to do exercise" Table 2 and Figure 1.

The major themes facilitating SM based on the action were as follows:

Appropriate usage of BGLDs has three major themes. One of the patients said, "I don't forget to take my medicine before meal and at mealtime".

Following a healthy diet has 4 major themes. One of the subjects stated, "My children have stress for eating sweets and are frustrated". Another patient said, "I know that adding salt and soda to bread increases blood sugar (BS) and blood pressure, and there are reasons for having a healthy diet".

Major factors in having PA that one of the subjects said "My friends encourage me to exercise" satisfaction of treatments and socio-economic status (SES) was two themes (Table 3 and Figure 2).

Patients with T2DM, who were in the pre-action group, claimed several factors as reasons for having or not having SM in the different stages of the study (Tables 4 and 5 and Figures 3 and 4).

Table 6 presents the comparison of the main features of inhibiting and facilitating factors in self-care in patients with T2DM in pre-action and action structures.

\section{Discussion}

In this mixed method study, the inhibiting and facilitating factors for SM of T2DM were investigated among a typical sample of Iranian patients based upon the SOC and decisional balance constructs of TTM. Patients who were in the action stage had higher scores in different parts of SM than patients in the pre-action stage, and also the action group had higher mean duration years of disease, higher percentage of family history of T2DM and educated 
Table 2 Codes, Sub-Themes and Major Themes Inhibiting SM Among T2DM Patient's Based on the Action Construct (Action and Maintenance)

\begin{tabular}{|c|c|c|}
\hline Appropriate Usage of BGLDs & \multirow[t]{2}{*}{ Sub-Themes } & \multirow[t]{2}{*}{ Major Themes } \\
\hline Codes & & \\
\hline $\begin{array}{l}\text { Heartburn due to medication, side effects, edema, renal cyst, chemical medicine's side effects, } \\
\text { fatigue, believing that medicine dissolves patient's flesh }\end{array}$ & Side effects of all the BGLDs & \multirow[t]{4}{*}{$\begin{array}{l}\text { Physical-intellectual } \\
\text { factors }\end{array}$} \\
\hline Using glibenclamide causes fatigue, hand tremor and worsens patient's situation & Side effects of one of the BGLDs & \\
\hline Forgetting to use the medication & Memory's weakness in remembering & \\
\hline Fear of using chemical medication & $\begin{array}{l}\text { Having misconceptions about drug } \\
\text { combination }\end{array}$ & \\
\hline Cost & Financial pressure & \multirow{2}{*}{$\begin{array}{l}\text { Socio-economic } \\
\text { situation }\end{array}$} \\
\hline Lack of access to medication because of being a driver & Unsuitable job & \\
\hline $\begin{array}{l}\text { Herbal medicine inefficiency, not using herbal medicines, using several drugs at the same time } \\
\text { and not being effective, unsuitable medicine, inefficiency of the drug on patient's condition }\end{array}$ & Improper drug administration & $\begin{array}{l}\text { Treatment team's } \\
\text { weak function }\end{array}$ \\
\hline Following a healthy diet & \multirow[t]{2}{*}{ Sub-themes } & \multirow[t]{2}{*}{ Major themes } \\
\hline Codes & & \\
\hline $\begin{array}{l}\text { Feeling dizzy when eating is delayed, body tremor due to food restriction, hand and feet } \\
\text { tremor in ceremonies, faint }\end{array}$ & $\begin{array}{l}\text { Faintness and tiredness when eating is } \\
\text { delayed }\end{array}$ & \multirow[t]{4}{*}{ Physical factors } \\
\hline $\begin{array}{l}\text { Extreme restriction leading to anemia, greedy eating when BS is low due to medication, eating } \\
\text { twice because sugar is not absorbed, eating more than dietary portions because satiety is not } \\
\text { achieved }\end{array}$ & Physical effects because of food restrictions & \\
\hline $\begin{array}{l}\text { Unwilling to eat because of consequences, being lazy, tempting to eat sweets, losing hope for } \\
\text { living, difficulties of eating }\end{array}$ & $\begin{array}{l}\text { The effect of mental and moral difficulties } \\
\text { on dietary observance }\end{array}$ & \\
\hline $\begin{array}{l}\text { Losing weight since the beginning of disease, eating too much because of high BS, not feeling } \\
\text { satiety due to anabolism and catabolism disorders }\end{array}$ & $\begin{array}{l}\text { The effect of disease on body, the nature of } \\
\text { the disease }\end{array}$ & \\
\hline $\begin{array}{l}\text { Separating food from family because of heartburn caused by medications, forcing to eat rice } \\
\text { due to family's unwilling to eat, family consuming too much rice, eating or not eating has no } \\
\text { effect on the child }\end{array}$ & Incoordination of the family & $\begin{array}{l}\text { Family and Social } \\
\text { status }\end{array}$ \\
\hline Lack of knowledge of appropriate diet for diabetic patients & $\begin{array}{l}\text { Lack of dietary education for diabetic patients } \\
\text { by nutritionist, Weakness management }\end{array}$ & $\begin{array}{l}\text { Treatment team's weak } \\
\text { function }\end{array}$ \\
\hline Having PA & \multirow[t]{2}{*}{ Sub-themes } & \multirow[t]{2}{*}{ Major themes } \\
\hline Codes & & \\
\hline $\begin{array}{l}\text { Feeling tired when working, high BS when dancing, having too much work to do, feeling } \\
\text { tiredness in the back and feet, arthrosis, fatigue after exercise, not having enough energy for } \\
\text { doing daily work at home, bradycardia when exercising, sitting down because of tiredness }\end{array}$ & Feeling tired and sick & \multirow[t]{4}{*}{$\begin{array}{l}\text { Physical-intellectual } \\
\text { factors }\end{array}$} \\
\hline $\begin{array}{l}\text { Excitement because of dancing, not willing to go outside, not having stress and resting, not willing to do } \\
\text { ordinary work, going to funerals causes lethargy and loosing functionality, laziness, being sedentary } \\
\text { because of lethargy, not willing to exercise because of family loss, not willing to exercise in the yard } \\
\text { because of bad memories, having too much work, not understanding the benefits of PA and its } \\
\text { consequences }\end{array}$ & Moral and mental difficulties & \\
\hline Being low active due to diabetes & $\begin{array}{l}\text { Effect of disease on activity, nature of } \\
\text { disease }\end{array}$ & \\
\hline Cold climate & Intolerance of cold & \\
\hline
\end{tabular}


Table 2 (Continued).

\begin{tabular}{|l|l|l|}
\hline Appropriate Usage of BGLDs & \multirow{2}{*}{ Sub-Themes } \\
\hline Codes & $\begin{array}{l}\text { Major Themes } \\
\text { apartment, not using treadmill }\end{array}$ & Facilities \\
\hline $\begin{array}{l}\text { Not working because of children's education, exercising alone, not willing to participate in } \\
\text { group activities }\end{array}$ & Lack of cooperation from family and friends & \\
\hline Difficulty of exercise or mountain climbing for women & Limitation of exercise due to gender \\
\hline Not having enough time & Time management \\
\hline
\end{tabular}

Abbreviations: T2DM, type 2 diabetes mellitus; SM, self-management; BS, blood sugar; PA, physical activity; BGLDs, blood-glucose-lowering drugs.

in relation SM than pre-action group. Despite the common inhibiting items observed in both groups, lack of planning was reported as one of the main inhibitors of action in comparison to the pre-action stage. This finding indicates that patients in the action stage value planning and try to overcome not having time as the inhibiting factor. However, patients in the pre-action stage did not indicate this factor and they believed in arbitrary treatment, which was the main reason of unlikeliest of SM.

Despite the major themes reported by both groups, patients who were in the pre-action stage, claimed religious and Islamic beliefs were as important factors. However, patients in the action stage paid attention to appropriate planning for suitable exercising, using medicine and traditional treatment which motivate them to keep up with SM.

In FGD, SES factors such as lack of facilities, lack of glucometer, doctor or dietitian visits payment and

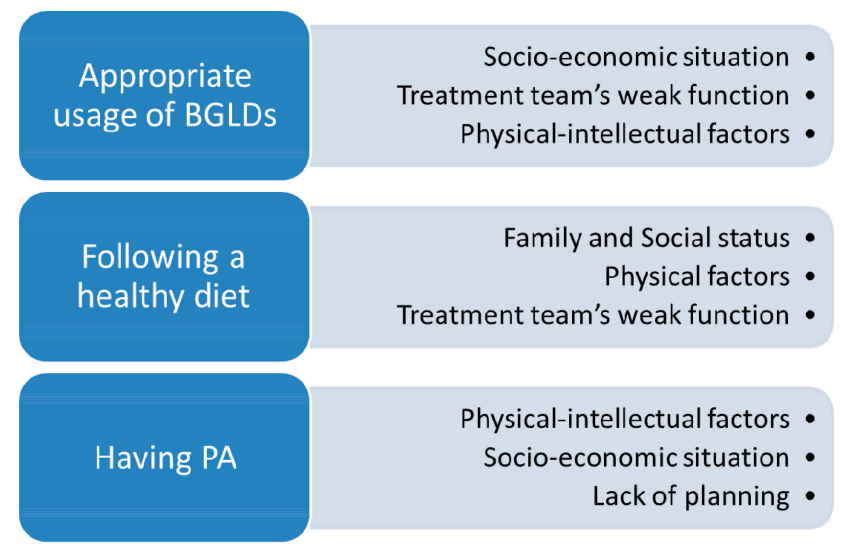

Figure I Major themes limiting self-management among patients with T2DM based on the action stage.

Abbreviations: BGLDs, blood-glucose-lowering drugs; PA, physical activity; T2DM, type 2 diabetes mellitus. medicine cost were indicated as the limitations of SM in both stages for several times. Similarly, in Mousavizadeh et al and Taha et al studies, financial pressure and social difficult situation were claimed as barriers of adherence to treatment and Fort et al indicated a lack of drug as a barrier in preparation of SOC. ${ }^{12,22,23}$ The difference between this study and Fort's study was the design of the study. We can overcome these problems by introducing these patients to health centers in the cities that provide medical services, ${ }^{24}$ nutritional counseling, psychology, free BS and cholesterol tests. However, suitable economic condition and having convenience are facilitators of SM.

In this study, based on the situation, both groups mentioned family and social factors as inhibitors and facilitators of SM. These findings were similar to previous studies. $^{12,22,25-29}$ Identifying family members especially daughters who can encourage and support patients about $\mathrm{SM}$ is an important supporting factor. This fact helps patients with T2DM obey their treatment because their role is very essential. Also, social institution and public organization's support could be an important facilitator in SM. In some customs and religions, due to cultural and social limitations, certain exercises are not possible for women. Thus, it is essential for public organizations to build special parks and places with SM facilities so that women could exercise.

Diabetes is a chronic disease, needing a vast amount of behavioral changes and complex dietary surveillance. Social support, as one of the efficient and important factors of patient adherence to treatment, can facilitate SM behaviors and compatibility with disease. ${ }^{10}$

In this study, few patients were unsatisfied of the treatment team's incomplete informing, that are not respondent and unsuitable education. Others declared treatment teams' good behavior, support, prescribing 
Table 3 Codes, Sub-Themes and Major Themes Facilitating SM Among T2DM Patient's Based on the Action Construct (Action and Maintenance)

\begin{tabular}{|c|c|c|}
\hline Appropriate Usage of BGLDs & \multirow[t]{2}{*}{ Sub-Themes } & \multirow{2}{*}{$\begin{array}{l}\text { Major } \\
\text { Themes }\end{array}$} \\
\hline Codes & & \\
\hline $\begin{array}{l}\text { Because of BS decline, because of not being hospitalized, not having effect on heart, kidney } \\
\text { and etc. reducing disease symptoms, not using medicine causes death, the necessity of } \\
\text { medication, blindness due to not using medicine }\end{array}$ & Improving symptoms consequences of usage BGLDs & $\begin{array}{l}\text { Satisfaction of } \\
\text { treatment }\end{array}$ \\
\hline $\begin{array}{l}\text { Using cranberry, nettles and fenugreek seeds, using herbal medicine, using honey wax and } \\
\text { peganumharmala for reducing BS }\end{array}$ & Using alternative treatment instead of chemical drugs & $\begin{array}{l}\text { Traditional } \\
\text { treatment }\end{array}$ \\
\hline $\begin{array}{l}\text { Remembering to use medicine before meal, having medicine at mealtime, not forgetting to } \\
\text { use medicine }\end{array}$ & Remembering to use medicine & Planning \\
\hline Following a healthy diet & \multirow[t]{2}{*}{ Sub-themes } & \multirow{2}{*}{$\begin{array}{l}\text { Major } \\
\text { themes }\end{array}$} \\
\hline Codes & & \\
\hline $\begin{array}{l}\text { Separating food from family, spouse and children having a healthy diet, spouse not } \\
\text { complaining about healthy diet, kids believing that disease is hereditary and they must have } \\
\text { a healthy diet, boys having a healthy diet, spouse being used to healthy diet }\end{array}$ & Family members having a healthy diet & \multirow[t]{3}{*}{$\begin{array}{l}\text { Socio- } \\
\text { economic } \\
\text { status }\end{array}$} \\
\hline Spouse and children having stress for eating sweets and being frustrated, children's worriedness & Family's concern regarding healthy diet & \\
\hline High medical costs & Preventing medical costs & \\
\hline $\begin{array}{l}\text { Not consuming sweets and having less rice, getting used to healthy diet, having less sweet } \\
\text { food, drinking apple vinegar for losing weight, knowing that sugar and sweet increases BS, } \\
\text { not using sweets because of renal and nephric side-effects, tiredness due to lack of energy } \\
\text { produced from carbohydrate, the effect of zucchini on BS, knowing that adding salt and soda } \\
\text { to bread dysregulates BS, not consuming fried foods, eating biscuits instead of cookie, Not } \\
\text { having the desire to eat sweets, hatreds form sugar, getting used to not eating sweets }\end{array}$ & $\begin{array}{l}\text { Having the knowledge and information regarding } \\
\text { dietary exchange list, Overcoming mental and } \\
\text { psychological barriers }\end{array}$ & $\begin{array}{l}\text { Having } \\
\text { nutritional } \\
\text { knowledge }\end{array}$ \\
\hline $\begin{array}{l}\text { Doctor, referring to dietitian, dietitian's recommendation to eat } 10 \text { spoons of rice, doctors } \\
\text { giving information to patients, doctor's recommendation to eat } 10 \text { spoons of rice }\end{array}$ & Doctors and dietitians educating patients & $\begin{array}{l}\text { Treatment } \\
\text { team's support }\end{array}$ \\
\hline $\begin{array}{l}\text { Fear of using Insulin, fear of hyper glycaemia, eating too much increases BS, eating less } \\
\text { because eating too much declines drugs effect, reducing symptoms of disease, not eating } \\
\text { because patients feel it will ruin their body }\end{array}$ & Understanding the consequences of disease & $\begin{array}{l}\text { Beliefs about } \\
\text { diabetes }\end{array}$ \\
\hline Having PA & \multirow[t]{2}{*}{ Sub-themes } & \multirow{2}{*}{$\begin{array}{l}\text { Major } \\
\text { themes }\end{array}$} \\
\hline Codes & & \\
\hline $\begin{array}{l}\text { Doing daily activities, walking while doing daily activities, participating in housework, accustomed to } \\
\text { exercise, forcing yourself to exercise despite having arthritis }\end{array}$ & \multirow{2}{*}{$\begin{array}{l}\text { Convincing yourself to be active and doing exercise, } \\
\text { Understanding the benefits of exercising in reducing } \\
\text { consequences of disease }\end{array}$} & \multirow[t]{2}{*}{$\begin{array}{l}\text { Satisfaction of } \\
\text { treatment }\end{array}$} \\
\hline $\begin{array}{l}\text { Reducing symptoms of disease, foot soaring reduced because of exercising, exercising for getting rid } \\
\text { of bad memories, exercising for combating disease, exercising and working makes you happy }\end{array}$ & & \\
\hline $\begin{array}{l}\text { Excusing children for going outside, encouraging children to exercise (walking), exercising in groups, } \\
\text { bringing children along while exercising, encouraging friends to exercise, exercising in groups in gyms }\end{array}$ & Encouraging family and friends to exercise & \multirow{5}{*}{$\begin{array}{l}\text { Socio- } \\
\text { economic } \\
\text { status }\end{array}$} \\
\hline Jogging is best for women & Encouraging women to exercise in acutance to their abilities & \\
\hline $\begin{array}{l}\text { Having spare time for exercising, mountain climbing on weekends, exercising at mornings, } \\
\text { jogging at home and recording the time, waking up early and exercising, doctor's } \\
\text { recommendation to exercise at evenings }\end{array}$ & Having spare time to exercise & \\
\hline Having exercise equipment and suitable shoes & Having facilities to exercise & \\
\hline $\begin{array}{l}\text { Exercising outside, walking around the Shourabil lake, going to gym, walking in the swimming } \\
\text { pool, swimming in the hot waters of Sarein, owning a villa }\end{array}$ & Having a suitable place for exercising & \\
\hline
\end{tabular}

Abbreviations: T2DM, type 2 diabetes mellitus; SM, self-management; BS, blood sugar; PA, physical activity; BGLDs, blood-glucose-lowering drugs. 


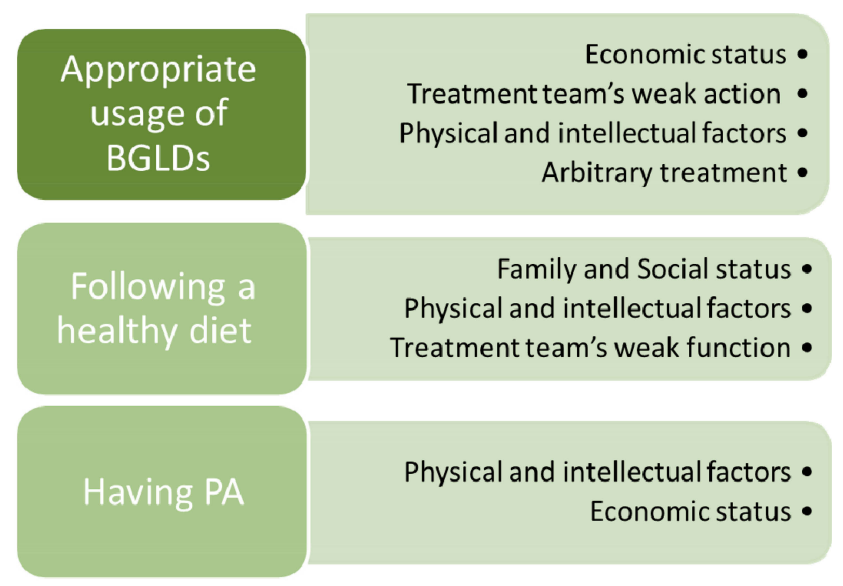

Figure 2 Major themes limiting self-management among patients with T2DM based on the pre-action stage.

Abbreviations: BGLDs, blood-glucose-lowering drugs; PA, physical activity; T2DM, type 2 diabetes mellitus.

accurate medicine and dietary education as encouraging factors for SM. They believed these behaviors were the reason for their adherence to treatment and continue referrals. These findings were similar to the results of many studies. ${ }^{22,25,30}$ Patient's satisfaction of the treatment team is an efficient factor in improving their adherence to treatment.

One of the main aspects preventing SM in the preaction group was arbitrary treatment. Usually, nonspecialist's recommendations and treatment provide wrong information about SM among T2DM patients. This fact leads to not using medicine or reducing its dose, failure of obeying diet or quitting exercise. These findings were in consistent with Shakibazadeh et al study. ${ }^{30}$

Additionally, similar to Shakibazadeh et al and Coornad et al studies, physical and intellectual factors were important factors that patients in the pre-action and action stages indicated as obstacles for SM. ${ }^{30,31}$ Due to the limitation of resources in developing countries, by overcoming physical and intellectual barriers we can achieve health and success in SM. In this study, patients in the action stage indicated overcoming intellectual, physical and psychological barriers as facilitating factors and they were able to overcome physical and psychological problems with this procedure. Also, they achieved higher scores in comparison to the pre-action group.

Similar to Carolan et al and Shaghaghi et al study, some of the barriers of SM in both the pre-action and action groups were the nature of the disease, physicalmental factors, losing weight after diabetes, not feeling satiety after eating and eating too much because of anabolism and catabolism dysfunction..$^{27,32}$

Continental features and climate were two of the aspects mentioned as inhibiting factors for exercising in the sub-themes of physical factors. In both groups, cold climate was the barrier of walking in outdoors. According to Salehi et al study, $11.5 \%$ of the study population claimed air pollution as the main barrier. ${ }^{33}$ In another study, cold or hot weather was mentioned as the main inhibitor of exercise. However, by exercising at home with inexpensive exercising equipment or public exercises patients can overcome this problem. ${ }^{12,34}$

In SM, planning was indicated as a facilitating factor, especially in patients who were in the action stage. In order to not forget to use their medication, these patients brought their medicine to the food table and so in PA, not having enough time was inhibiting SM. Similar to few other studies, not having enough time and not planning for exercising were mentioned as limiting factors. ${ }^{35,36}$

In the action group, beliefs about diabetes such as understanding the longtime consequences of diabetes were mentioned as the facilitating and inhibiting factors. In the pre-action group, fear of amputation and high BS were claimed as facilitators of SM. In Doosti's study, fear was indicated as a facilitating factor. Fear is a common respond effecting both patient and his/her family positively or negatively. In few patients, fear changes behavior positively and helps learn new things. In Shakibazadeh's study, fear was reported as a motivating factor. ${ }^{10,30}$

Gaining information and knowledge about physical condition was one of the major themes, introduced as a facilitator for referral to doctor and controlling BS in both groups. In Fort's study, lack of knowledge about the disease was another inhibiting factor in SM. However, in Doosti's study, this factor was indicated as a motivator for SM. ${ }^{10,12}$

Similar to Dehghani's study, religious beliefs were facilitating factors that were mentioned in the pre-action stage. ${ }^{37}$ In another study, adolescents who earned higher scores in religious beliefs had lower HbA1C. Religious beliefs help diabetic adolescents overcome stressful situations and should be considered as an important feature in treatment. ${ }^{38}$ Gaining information about the exchange list and reducing sweets and fats were considered as the facilitating factors of healthy diet in both groups. They claimed that by obtaining nutritional knowledge and information they could be successful in having a healthy diet. Similar results were also observed in another study. ${ }^{27}$ 
Table 4 Codes, Sub-Themes and Major Themes Inhibiting Adherence to SM Among T2DM Patient's Based on the Pre-Action Construct (Pre-Contemplation, Contemplation and Preparation)

\begin{tabular}{|c|c|c|}
\hline Appropriate Usage of BGLDs & \multirow[t]{2}{*}{ Sub-Themes } & \multirow[t]{2}{*}{ Major Themes } \\
\hline Codes & & \\
\hline $\begin{array}{l}\text { Medication finished, not having money to buy medication } \\
\text { Forgetting to consume medicine, depression due to chemical drugs, heartburn }\end{array}$ & $\begin{array}{l}\text { Lack of financial facilities } \\
\text { Memory dysfunction, drug side } \\
\text { effects }\end{array}$ & $\begin{array}{l}\text { Economic status } \\
\text { Physical and intellectual } \\
\text { factors }\end{array}$ \\
\hline No difference between thirst and general feeling & $\begin{array}{l}\text { Not prescribing the suitable } \\
\text { dose }\end{array}$ & $\begin{array}{l}\text { Treatment team's weak } \\
\text { action }\end{array}$ \\
\hline Using herbal drugs and liking their soothing feeling instead of BGLDs & $\begin{array}{l}\text { Inappropriate use of herbal } \\
\text { drugs instead of chemical drugs }\end{array}$ & Arbitrary treatment \\
\hline Following a healthy diet & \multirow[t]{2}{*}{ Sub-themes } & \multirow[t]{2}{*}{ Major themes } \\
\hline Codes & & \\
\hline Not always obeying the diet specially in parties, ceremonies or at home & $\begin{array}{l}\text { Not obeying the diet in certain } \\
\text { ceremonies }\end{array}$ & \multirow[t]{2}{*}{ Family and Social status } \\
\hline $\begin{array}{l}\text { Spouse's insistence to eat food, spouse baking sweets, patient eating food when } \\
\text { he/she sees others eat, spouse does not cooperate because he is a driver, others } \\
\text { make him/her angry and cause overeating }\end{array}$ & $\begin{array}{l}\text { Lack of coordination in the } \\
\text { family }\end{array}$ & \\
\hline $\begin{array}{l}\text { Temptation and angriness causes overeating, angriness causes inappropriate food } \\
\text { restrictions, feeling lazy, shivering }\end{array}$ & $\begin{array}{l}\text { Effect of mental problems on } \\
\text { having a diet }\end{array}$ & \multirow[t]{3}{*}{$\begin{array}{l}\text { Physical and intellectual } \\
\text { factors }\end{array}$} \\
\hline $\begin{array}{l}\text { Overeating because of the side-effects of BGLDs, weakness because of the effect } \\
\text { of drugs and overeating }\end{array}$ & $\begin{array}{l}\text { Feeling weak because of the } \\
\text { consequences of drugs }\end{array}$ & \\
\hline High BS leads to overeating, thyroid dysfunction leads to overeating & $\begin{array}{l}\text { The effect of medicine on body, } \\
\text { the nature of the disease }\end{array}$ & \\
\hline $\begin{array}{l}\text { Using herbal plants for losing weight, getting rid of the remaining oil after frying } \\
\text { food }\end{array}$ & $\begin{array}{l}\text { Not participating in educational } \\
\text { programs for losing weight }\end{array}$ & \multirow[t]{2}{*}{$\begin{array}{l}\text { Treatment team's weak } \\
\text { function }\end{array}$} \\
\hline Small amount of food in the prescribed diet & Not providing a suitable diet & \\
\hline Having PA & \multirow[t]{2}{*}{ Sub-Themes } & \multirow[t]{2}{*}{ Major themes } \\
\hline Codes & & \\
\hline Cold climate, cold climate effecting kidney & Climate & \multirow{3}{*}{$\begin{array}{l}\text { Physical and intellectual } \\
\text { factors }\end{array}$} \\
\hline $\begin{array}{l}\text { Having pain in the body or feet, Arthritis, high BS causes pain, having problem in } \\
\text { the feet }\end{array}$ & Disease and physical problems & \\
\hline Laziness, not feeling good, tiredness, sleeping & $\begin{array}{l}\text { Mental and physiological } \\
\text { problems }\end{array}$ & \\
\hline Going out by car, going out by car with children, not owning a bicycle to use it & Lack of facilities & Economic status \\
\hline
\end{tabular}

Abbreviations: T2DM, type 2 diabetes mellitus; SM, self-management; BS, blood sugar; PA, physical activity; BGLDs, blood-glucose-lowering drugs.

Another facilitator was overcoming intellectualpsychological factors. These factors were considered as sub-themes of physical-intellectual factors in the action stage. Self-efficiency has been related to the barriers of SM. This relationship indicates that patients who have higher self-efficiency feel fewer obstacles in the procedure of SM and have more SM activities. ${ }^{39,40}$

Traditional or alternative treatment was considered as a facilitator in SM in the action stage. Herbs such as cranberry, Nettles and Fenugreek seeds, walnut and 
Table 5 Codes, Sub-Themes and Major Themes Facilitating SM Among T2DM Patient's Based on the Pre-Action Construct (PreContemplation, Contemplation and Preparation)

\begin{tabular}{|c|c|c|}
\hline Appropriate Usage of BGLDs & \multirow[t]{2}{*}{ Sub-Themes } & \multirow{2}{*}{$\begin{array}{l}\text { Major } \\
\text { Themes }\end{array}$} \\
\hline Codes & & \\
\hline $\begin{array}{l}\text { Feeling better and symptoms reducing because of medicine, not using medicine leads } \\
\text { to inactiveness, feeling tired when not consuming medicine, vision obstruction } \\
\text { because of not using medicine, feeling bad due to not using medicine }\end{array}$ & General status getting better & $\begin{array}{l}\text { Satisfaction of } \\
\text { treatment }\end{array}$ \\
\hline Fear of hospitalization and hyperglycemia because of not using medicine & Fear of the consequences of disease & $\begin{array}{l}\text { Beliefs } \\
\text { regarding } \\
\text { diabetes }\end{array}$ \\
\hline Doctor prescribing herbal medicine & $\begin{array}{l}\text { Doctor using alternative treatment } \\
\text { instead of chemical drugs }\end{array}$ & $\begin{array}{l}\text { Traditional } \\
\text { treatment }\end{array}$ \\
\hline Following a healthy diet & \multirow[t]{2}{*}{ Sub-themes } & \multirow[t]{2}{*}{ Major themes } \\
\hline Codes & & \\
\hline $\begin{array}{l}\text { Doctor prescribing a diet, reducing the amount of food by a dietitian, asking the } \\
\text { amount of food before prescribing by a dietitian }\end{array}$ & $\begin{array}{l}\text { Educating diet by a doctor and by } \\
\text { a dietitian }\end{array}$ & $\begin{array}{l}\text { Treatment } \\
\text { team's support }\end{array}$ \\
\hline Spouse insistence to have a diet, the whole family having a healthy diet & $\begin{array}{l}\text { Family member's cooperation in } \\
\text { having a healthy diet }\end{array}$ & \multirow[t]{2}{*}{ Social status } \\
\hline Not being disabled, because of others & $\begin{array}{l}\text { Family's concern regarding the } \\
\text { consequences of disease }\end{array}$ & \\
\hline $\begin{array}{l}\text { Not eating unhealthy food, eating less rice, not eating sweets and cookies, eating fruits } \\
\text { and vegetables when feeling weak, not consuming sugar, food avoidance, being on } \\
\text { a diet in Ramadan }\end{array}$ & $\begin{array}{l}\text { Awareness and having knowledge } \\
\text { regarding the food exchange list }\end{array}$ & $\begin{array}{l}\text { Having } \\
\text { nutritional } \\
\text { knowledge }\end{array}$ \\
\hline $\begin{array}{l}\text { Losing weight improves general condition, food avoidance improves general condition, } \\
\text { consuming fats worsens the condition, eating less food helps control BS }\end{array}$ & General condition improving & $\begin{array}{l}\text { Satisfaction of } \\
\text { diet therapy }\end{array}$ \\
\hline Having PA & \multirow[t]{2}{*}{ Sub-themes } & \multirow[t]{2}{*}{ Major themes } \\
\hline Codes & & \\
\hline $\begin{array}{l}\text { Doctor's recommendations, Walking after being frustrated, exercising while being } \\
\text { tired }\end{array}$ & $\begin{array}{l}\text { Doctor's instructions, For improving } \\
\text { mentality }\end{array}$ & $\begin{array}{l}\text { Treatment } \\
\text { team's support }\end{array}$ \\
\hline Having a yard or gym & Having a suitable place for exercising & \multirow{2}{*}{$\begin{array}{l}\text { Economic } \\
\text { status }\end{array}$} \\
\hline $\begin{array}{l}\text { Feeling good after exercising, feeling depressed because of not exercising, because of } \\
\text { low BS }\end{array}$ & Improvement after exercise & \\
\hline Going to Mecca & Feeling peace in holly places & $\begin{array}{l}\text { Religious and } \\
\text { Islamic beliefs }\end{array}$ \\
\hline
\end{tabular}

Abbreviations: T2DM, type 2 diabetes mellitus; SM, self-management; BS, blood sugar; PA, physical activity; BGLDs, blood-glucose-lowering drugs.

olive leaves were reported as herbals that reduce BS and could be used along diabetes controlling drugs. These findings were similar to two review studies. ${ }^{8,9,41}$ Before the discovery of insulin and anti-diabetes medicine, patients with diabetes were treated with traditional and herbal drugs. Until now, 1200 herbal plants have been discovered to be useful in reducing BS and its consequences. $^{42}$
The strength of this study was the use of mixed methods design and also, was using the trans theoretical model. In this study, patients were divided into pre-action and action groups and assessed based on different levels of self-management. The facilitating and inhibiting factors were assessed separately in both groups.

The limitations of our study were using semi-structured questions, considering patients with different educational 


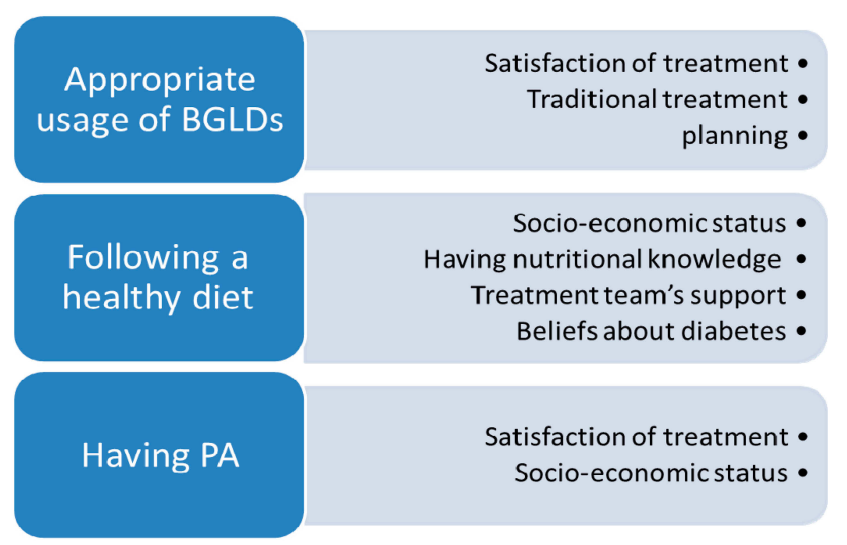

Figure 3 Major themes facilitating self-management among patients with T2DM based on the action stage.

Abbreviations: BGLDs, blood-glucose-lowering drugs; PA, physical activity; T2DM, type 2 diabetes mellitus.

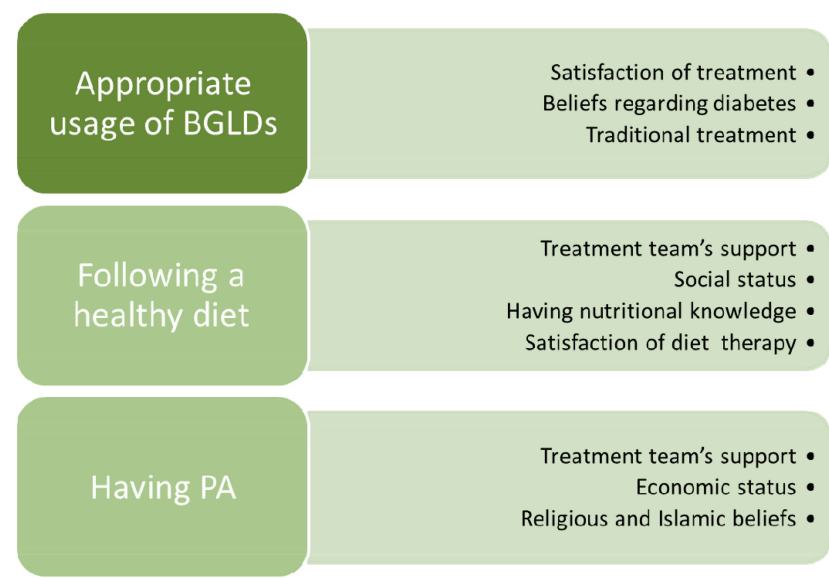

Figure 4 Major themes facilitating self-management among patients with T2DM based on the pre-action stage.

Abbreviations: BGLDs, blood-glucose-lowering drugs; PA, physical activity; T2DM, type 2 diabetes mellitus.

levels, economic status and accomplishing the study in a specialized clinic outside the diabetes clinic.

\section{Recommendations}

Determining the facilitating and inhibiting factors of SM can be useful in judging the success or failure of SM among T2DM patients. In this case the members of the therapeutic team can plan suitable interventional programs such as SM education in order to have efficient results.

By considering educational barriers, we can explore suitable programming to overcome these obstacles. Also by exploiting the facilitating factors of SM, we can use them as motivating factors for SM and as basics of treatment. The therapeutic team could use this aspect in counseling and educational sessions. Thus, it is
Table 6 Comparison of the Main Features of Inhibiting and Facilitating Factors in Self-Care in Patients with T2DM in PreAction $(n=10)$ and Action Structures $(n=12)$

\begin{tabular}{|c|c|c|c|}
\hline \multicolumn{2}{|l|}{ Inhibiting } & \multicolumn{2}{|l|}{ Facilitating } \\
\hline Action & Pre-Action & Action & Pre-Action \\
\hline \multicolumn{2}{|c|}{ Appropriate Usage of BGLDs } & \multicolumn{2}{|c|}{ Appropriate Usage of BGLDs } \\
\hline $\begin{array}{l}\text { Physical- } \\
\text { intellectual } \\
\text { factors }\end{array}$ & $\begin{array}{l}\text { Physical and } \\
\text { intellectual } \\
\text { factors }\end{array}$ & $\begin{array}{l}\text { Satisfaction of } \\
\text { treatment }\end{array}$ & $\begin{array}{l}\text { Satisfaction of } \\
\text { treatment }\end{array}$ \\
\hline $\begin{array}{l}\text { Socio- } \\
\text { economic } \\
\text { situation }\end{array}$ & $\begin{array}{l}\text { Economic } \\
\text { status }\end{array}$ & $\begin{array}{l}\text { Traditional } \\
\text { treatment }\end{array}$ & $\begin{array}{l}\text { Traditional } \\
\text { treatment }\end{array}$ \\
\hline \multirow[t]{2}{*}{$\begin{array}{l}\text { Treatment } \\
\text { team's weak } \\
\text { function }\end{array}$} & $\begin{array}{l}\text { Treatment } \\
\text { team's weak } \\
\text { action }\end{array}$ & Planning & $\begin{array}{l}\text { Beliefs } \\
\text { regarding } \\
\text { diabetes }\end{array}$ \\
\hline & $\begin{array}{l}\text { Arbitrary } \\
\text { treatment }\end{array}$ & & \\
\hline \multicolumn{2}{|c|}{ Following a healthy diet } & \multicolumn{2}{|c|}{ Following a healthy diet } \\
\hline $\begin{array}{l}\text { Family and } \\
\text { Social status }\end{array}$ & $\begin{array}{l}\text { Family and } \\
\text { Social status }\end{array}$ & $\begin{array}{l}\text { Socio- } \\
\text { economic } \\
\text { status }\end{array}$ & Social status \\
\hline Physical factors & $\begin{array}{l}\text { Physical- } \\
\text { intellectual } \\
\text { factors }\end{array}$ & $\begin{array}{l}\text { Having } \\
\text { nutritional } \\
\text { knowledge }\end{array}$ & $\begin{array}{l}\text { Having } \\
\text { nutritional } \\
\text { knowledge }\end{array}$ \\
\hline \multirow[t]{2}{*}{$\begin{array}{l}\text { Treatment } \\
\text { team's weak } \\
\text { function }\end{array}$} & \multirow[t]{2}{*}{$\begin{array}{l}\text { Treatment } \\
\text { team's weak } \\
\text { function }\end{array}$} & $\begin{array}{l}\text { Treatment } \\
\text { team's } \\
\text { support }\end{array}$ & $\begin{array}{l}\text { Treatment } \\
\text { team's support }\end{array}$ \\
\hline & & $\begin{array}{l}\text { Beliefs about } \\
\text { diabetes }\end{array}$ & $\begin{array}{l}\text { Satisfaction of } \\
\text { diet therapy }\end{array}$ \\
\hline \multicolumn{2}{|l|}{ Having PA } & \multicolumn{2}{|l|}{ Having PA } \\
\hline $\begin{array}{l}\text { Physical- } \\
\text { intellectual } \\
\text { factors }\end{array}$ & $\begin{array}{l}\text { Physical- } \\
\text { intellectual } \\
\text { factors }\end{array}$ & $\begin{array}{l}\text { Satisfaction of } \\
\text { treatment }\end{array}$ & $\begin{array}{l}\text { Treatment } \\
\text { team's support }\end{array}$ \\
\hline $\begin{array}{l}\text { Socio- } \\
\text { economic } \\
\text { situation }\end{array}$ & $\begin{array}{l}\text { Economic } \\
\text { status }\end{array}$ & $\begin{array}{l}\text { Socio- } \\
\text { economic } \\
\text { status }\end{array}$ & $\begin{array}{l}\text { Economic } \\
\text { status }\end{array}$ \\
\hline $\begin{array}{l}\text { Lack of } \\
\text { planning }\end{array}$ & & & $\begin{array}{l}\text { Religious and } \\
\text { Islamic beliefs }\end{array}$ \\
\hline
\end{tabular}

Abbreviations: BGLDs, blood-glucose-lowering drugs; PA, physical activity; T2DM, Type 2 diabetes mellitus.

superior that effective family members participate in educational programs alongside patients to be aware of the procedure of the treatment. In fact, this action could motivate patients to continue their cooperation and their adherence to SM. 


\section{Conclusion}

In summary, this study is the first research in the field of assessing the inhibitors and facilitators of SM among T2DM patients based on SOC and decisional balance constructs of the TTM. Patients with T2DM in action group because had higher mean duration years of disease, higher percentage of family history of T2DM and educated in relation SM than pre-action group; therefore, the action group was more successful in planning for SM, increasing awareness in field diabetes, perception SES and overcome on barriers of SM compared to pre-action group.

\section{Abbreviations}

BGLDs, blood-glucose-lowering drugs; BS, blood sugar; FBG, fasting blood glucose; FGD, focus group discussions; PA, physical activity; SM, self-management; SOC, stages of change; T2DM, type 2 diabetes mellitus; TTM, trans theoretical model; HBA1C, glycated hemoglobin.

\section{Compliance with Ethics Guidelines}

This study was conducted according to the guidelines laid down in the Declaration of Helsinki and all procedures involving human subjects were approved by the deputy of research and ethics committee of Tabriz University of Medical Sciences, Iran (approval code: IR.TBZMED. REC.1395.1012). Written informed consent was completed for each participant. Written informed consent to publish was completed from the participant to report individual patient data.

\section{Acknowledgments}

We acknowledge participants and nutrition clinic staff and personals that have cooperated to the current study. We acknowledge Hamed Rezakhani Moghaddam, Assistant Professor of Health Education and Promotion, Department of Public Health, School of Medical Sciences, Khalkhal Faculty of Medical Sciences, which has helped in response to reviewer comments.

\section{Disclosure}

No potential conflicts of interest relevant to this article were reported.

\section{References}

1. Association AD. Diagnosis and classification of diabetes mellitus. Diabetes Care. 2014;37(Supplement 1):S81-S90.
2. Organization WH. Global report on diabetes [Internet]. 2016. 2017. Disponible sur: http://apps.who.int/iris/bitstream/10665/204871/1/ 9789241565257_eng. pdf. Accessed June 26, 2020.

3. Coventry PA, Bower P, Blakemore A, et al. Comparison of active treatments for impaired glucose regulation: a Salford Royal Foundation Trust and Hitachi collaboration (CATFISH): study protocol for a randomized controlled trial. Trials. 2016;17(1):424. doi:10.1186/s13063-016-1519-6

4. Busetto L, Luijkx K, Huizing A, Vrijhoef B. Implementation of integrated care for diabetes mellitus type 2 by two Dutch care groups: a case study. BMC Fam Pract. 2015;16(1):105. doi:10.1186/s12875-015-0320-z

5. Taggart L, Coates V, Clarke M, et al. A study protocol for a pilot randomised trial of a structured education programme for the self-management of type 2 diabetes for adults with intellectual disabilities. Trials. 2015;16(1):148. doi:10.1186/s13063-015-0644-y

6. Werfalli M, Raubenheimer P, Engel $M$, et al. Effectiveness of community-based peer-led diabetes self-management programmes (COMP-DSMP) for improving clinical outcomes and quality of life of adults with diabetes in primary care settings in low and middle-income countries (LMIC): a systematic review and meta-analysis. BMJ Open. 2015;5(7):e007635.

7. Tazakori Z, Zare M, Jafarabadi MA. Probiotic yogurt effect on macronutrients ingredients, blood glucose and lipid profile in type 2 diabetes. J Pak Med Assoc. 2017;67(7):1123.

8. Al Hamid A, Ghaleb M, Aljadhey H, Aslanpour Z. A systematic review of qualitative research on the contributory factors leading to medicine-related problems from the perspectives of adult patients with cardiovascular diseases and diabetes mellitus. BMJ Open. 2014;4(9):e005992. doi:10.1136/bmjopen-2014-005992

9. Majeed-Ariss R, Jackson C, Knapp P, Cheater FM. A systematic review of research into black and ethnic minority patients' views on self-management of type 2 diabetes. Health Expectations. 2015;18 (5):625-642. doi:10.1111/hex.12080

10. Doosti Irani M, Abazari P, Babaei S, Shahgholian N. Facilitators of adherence to self-management in type 2 diabetic patients: a phenomenological study. Iran J Endocrinol Metab. 2009;11(3):257-264.

11. Abdoli S, Ashktorab T, Ahmadi F, Parvizi S. Barriers to and facilitators of empowerment in people with diabetes. Iran J Endocrinol Metab. 2009;10(5):455-464.

12. Fort MP, Alvarado-Molina N, Peña L, Montano CM, Murrillo S, Martínez H. Barriers and facilitating factors for disease selfmanagement: a qualitative analysis of perceptions of patients receiving care for type 2 diabetes and/or hypertension in San José, Costa Rica and Tuxtla Gutiérrez, Mexico. BMC Fam Pract. 2013;14 (1):131. doi:10.1186/1471-2296-14-131

13. Baharvand-Ahmadi B, Bahmani M, Tajeddini P, Naghdi N, Rafieian-Kopaei M. An ethno-medicinal study of medicinal plants used for the treatment of diabetes. J Nephropathol. 2016;5(1):44. doi:10.15171/jnp.2016.08

14. Di Noia J, Prochaska JO. Mediating variables in a transtheoretical model dietary intervention program. Health Educ Behav. 2010;37 (5):753-762. doi:10.1177/1090198109334897

15. Zare M, Tarighat-Esfanjani A, Rafraf M, Shaghaghi A, Jafarabadi MA, Iranparvar-Alamdari M. Segmentation of Iranian type 2 diabetes patients based on the transtheoretical model of behavior change. J Biochem Tech. 2019;2:23-33.

16. Franz M. Medical nutrition theraphy for diabetes mellitus and hypoglycemia of nondiabetic origin. In: Mahan LK, Stump SE, editors. Krause's Food and the Nutrition Care Process. Dalam: Elsevier, Saunders; 2012;678-682.

17. Association AD. 15. Diabetes advocacy: standards of medical care in diabetes - 2018. Diabetes Care. 2018;41(Supplement 1):S152-S153. doi:10.2337/dc18-S015

18. Zare M, Rafraf M, Shaghaghi A, Jafarabadi MA, Tarighat-Esfanjani A. Developing a valid and reliable questionnaire of the stages of change in self-management of patients with type 2 diabetes among an Iranian population. Crescent J Medi Biol Sci. 2020;7(2):225-232. 
19. Newcomer KE, Hatry HP, Wholey JS. Focus Group Interviewing. Handbook of Practical Program Evaluation. Wiley Imprint; 2015:506.

20. Salsali M, Adib Hajbagheri M, Parvizy S. Qualitative Research Methods. Boshra Co; 2007.

21. Matlabi Fard A, Nave Ebrahim A, Lotfi L. Behavioral markers of higher education directors according to qualitative approaches based on content analysis. $Q J$ Educ Leadersh Admin. 2012;6(2):87-109.

22. Mousavizadeh S, Ashktorab T, Ahmadi F, Zandi M. Evaluation of barriers to adherence to therapy in patients with diabetes. $J$ Diabetes Nurs. 2016;4(3):94-108.

23. Taha NM, ABD El-azeaz M, ABD El-razik BG. Factors affecting compliance of diabetic patients toward therapeutic management. Med J Cairo Univ. 2011;79:2.

24. Rezakhani Moghaddam H, Allahverdipour H, Matlabi H. Barriers to women's participation: experiences of volunteers and community healthcare authorities. Soc Work Public Health. 2018;33 (4):237-249. doi:10.1080/19371918.2018.1454870

25. Laranjo L, Neves AL, Costa A, Ribeiro RT, Couto L, Sá AB. Facilitators, barriers and expectations in the self-management of type 2 diabetes - a qualitative study from Portugal. Eur J Gen Pract. 2015;21(2):103-110. doi:10.3109/13814788.2014.1000855

26. Mayberry LS, Osborn CY. Family support, medication adherence, and glycemic control among adults with type 2 diabetes. Diabetes Care. 2012;35(6):1239-1245. doi:10.2337/dc11-2103

27. Carolan M, Holman J, Ferrari M. Experiences of diabetes self-management: a focus group study among Australians with type 2 diabetes. J Clin Nurs. 2015;24(7-8):1011-1023. doi:10.1111/jocn.12724

28. Shen H, Edwards H, Courtney M, McDowell J, Wei J. Barriers and facilitators to diabetes self-management: perspectives of older community dwellers and health professionals in China. Int J Nurs Pract. 2013;19(6):627-635. doi:10.1111/ijn.12114

29. Alam R, Speed S, Beaver K. A scoping review on the experiences and preferences in accessing diabetes-related healthcare information and services by British Bangladeshis. Health Soc Care Community. 2012;20(2):155-171. doi:10.1111/j.1365-2524.2011.01027.x

30. Shakibazadeh A, Larichani B, Rashidian A, et al. Comparing type II diabetic patient's perspective with diabetes special staff regrading factors efficient on self-management: qualitative study. Iran j Diabetes Metab. 2009;9(2):142-151.
31. Coonrod BA. Overcoming physical barriers to diabetes self-care: reframing disability as an opportunity for ingenuity. Diabetes Spect. 2001;14(1):28-32. doi:10.2337/diaspect.14.1.28

32. Shaghaghi A, Ahmadi A, Matlabi H. Iranian patients require more pertinent care to prevent type 2 diabetes complications. Adv Prev Med. 2014;2014. doi:10.1155/2014/409391

33. Deforche B, De Bourdeaudhuij I. Differences in psychosocial determinants of physical activity in older adults participating in organised versus non-organised activities. J Sports Med Phys Fitness. 2000;40(4):362.

34. Salihi L, Eftekhar H, Mohammad K, Taghdisi MH, Shojaeizadeh D. Physical activity among a sample of Iranians aged over 60 years: an application of the transtheoretical model. Arch Iran Med. 2010;13 (6):528-536.

35. Rubin RR. Adherence to pharmacologic therapy in patients with type 2 diabetes mellitus. Am J Med. 2005;118(5):27-34. doi:10.1016/j. amjmed.2005.04.012

36. Lees FD, Clark PG, Nigg CR, Newman P. Barriers to exercise behavior among older adults: a focus-group study. J Aging Phys Act. 2005;13(1):23-33. doi:10.1123/japa.13.1.23

37. Dehghani T, Mazloumi Mahmoud Abad S, Marouti Sharif Abad M. Assessing facilitators and inhibitors of self-management based on Ardakan diabetic patient's perspective and services provided to them according to social marketing model. J Qual Res Health Sci. 2014;3(4):317-330.

38. Parsian N. Spirituality and Coping in Young Adults with Diabetes. Deakin University; 2008.

39. Shakibazadeh E, Rashidian A, Larijani B, Shojaeezadeh D, Forouzanfar M, Karimi Shahanjarini A. Perceived barriers and self-efficacy: impact on self-care behaviors in adults with type 2 diabetes. J Hayat. 2010;15(4):69-78.

40. Chlebowy DO, Garvin BJ. Social support, self-efficacy, and outcome expectations. Diabetes Educ. 2006;32(5):777-786. doi:10.1177/ 0145721706291760

41. Namazi N, Bahrami A. Effect of hydro-alcoholic nettle extract on lipid profiles and blood pressure in type 2 diabetes patients. Iran $J$ Endocrinol Metab. 2012;13(5):449-458.

42. Tazakkori Z, Zare M, Nemadi Vosoughi M, Tarighat-Esfanjani A. Nutrition and Die Therapy in Nursing. Tehran: Sociologist publishing; 2020:234. [Persian].

Diabetes, Metabolic Syndrome and Obesity: Targets and Therapy

Dovepress

\section{Publish your work in this journal}

Diabetes, Metabolic Syndrome and Obesity: Targets and Therapy is an international, peer-reviewed open-access journal committed to the rapid publication of the latest laboratory and clinical findings in the fields of diabetes, metabolic syndrome and obesity research. Original research, review, case reports, hypothesis formation, expert opinion and commentaries are all considered for publication. The manuscript management system is completely online and includes a very quick and fair peer-review system, which is all easy to use. Visit http://www.dovepress.com/testimonials.php to read real quotes from published authors. 